\title{
Analysis of the Characteristics of the Land Creeping (Slow-Moving) at Seomyeon, Suncheon-Si Area
}

Jae hyeon park ( $\nabla$ pjh@gntech.ac.kr)

Gyeongsang National University https://orcid.org/0000-0002-1446-7547

\section{Research Article}

Keywords: land creeping, dispersibility of soil, forest road cut, landslide hazard grade, Slow-moving landslide, Erode control soil

Posted Date: January 3rd, 2022

DOI: https://doi.org/10.21203/rs.3.rs-1113197/v1

License: (c) (i) This work is licensed under a Creative Commons Attribution 4.0 International License. Read Full License 


\section{Abstract}

This study was conducted to prevent land creeping by examining various features such as geology, topography, and physical characteristics, using the case of a land-crawled region. The first land creeping occurred in Seomyeon Suncheon-si in 2000, and the second occurred in 2020; the damaged surface area of the second event was approximately 21.7 times that of the first, and it was discovered Sunchoen-si Landcreep occur because of forest road cut affected. After $1 \mathrm{~h}$, it was moderate at a soil depth of 20, 100, 200 , and $250 \mathrm{~cm}$ from the surface soil, according to a measurement result of soil dispersity. It was severe at soil depths of 100,200 , and $250 \mathrm{~cm}$, and the clay soil between the bedrock was mild to severe, and it was determined to be severe in locations where groundwater was leaching. The objective study area was a typical land creeping-type landslide caused by weathered rocks, and this area belonged to a type of convex terrain ground ( () form. The land creeping occurred in the convex area ( $\square$ ). As a result of analyzing the landslide hazard grade, the creeping land area is found to be different from ordinary landslides because it includes most areas of landslide hazard grade 3-5 and out of the grade. Results show that the land creeping has proceeded in the directions of $\mathrm{S} 15^{\circ} \mathrm{E}, \mathrm{S} 20^{\circ} \mathrm{E}, \mathrm{S} 25^{\circ} \mathrm{E}$, and $\mathrm{S} 30^{\circ} \mathrm{E}$, which is consistent with the direction following the flow duration of groundwater determined using the electrical resistivity survey method.

\section{Introduction}

The term "land creeping" used in this paper is expressed as a phenomenon in Korea, in which a part of the soil layer continues to gradually and consistently slide and move while maintaining some extent of its original condition toward a lower area along a part in weak shear resistance or adhesion in the ground caused by groundwater on a mountain slope or slope face composed mainly of soil or rock layers. Distinguish it from ordinary landslides caused by heavy rains is often difficult. "Land creeping" has a tendency to occur intensively on a zone with specific geology or geological structure, existing due to the presence of an impermeable layer on the sliding surface, which often occurs when the soil layer acts as an active lubricant due to the presence of groundwater; in such a zone composed of shale, mudstone, tuff, etc. and in the case of Japan, this phenomenon is observed. In other countries, "land creeping" refers to the slow descent of rocks or dirt from a downhill. It is explained as soil deformation due to long-term pressure. The investigators may consider it as a continuous phenomenon, but it is defined as a minute and discontinuous movement caused by gravity.

In Korea, the land creeping has existed for a long time, but there has been no exposure before looking for large-scale mountainous areas. Currently, a tendency is being exposed due to tensile cracking and collapsing resulting from slope cutting or natural phenomena caused by various development activities (Park, 2018).

In Korea, until the 1970s, numerous shallow landslides had occurred because of erosion and loss of the soil due to mountain degradation (Choi, 2018). Currently, studies regarding the land creeping in Korea are being conducted for finding the creeping land area by analyzing topographic maps and aerial 
photographs caused by the deformation of microtopography due to long-term ground movement (Park et al., 2021) and the geological and topographical characteristics of the creeping land area (Davis, 1899; Takaya, 2017), along with the research regarding restoration measures (National Institute of Forest Science, 2017). The land creeping occurs in the relationship between clay stratum in the soil and rainfalls (Culling, 1963; Jau et al., 2000) and is also caused due to the collapse of discontinuity surface and fragmental zone of fault (Tomio et al., 1990; Park et al., 2003; 2005; Kim, 2004). It is caused by freezing and thawing (Auzet and Ambroise, 1996) or increase in the groundwater level (Matsukura et al., 1983; Anderson and Richards, 1987; Montgomery et al., 1998), as well as artificial development, such as forest road opening (Park et al., 2003; National Institute of Forest Science, 2017). Therefore, this study has been conducted to provide basic data for preventing damages caused by land creeping by analyzing the characteristics of the creeping land area around San 41, Pangyo-ri, Seomyeon, Suncheon-si, Jeolla-namdo, Korea.

\section{Material And Methods}

The vegetation spread in the land crept area (Fig. 1) around at San 41, Pangyo-ri, Seo-myeon, Suncheonsi, Jeol-la-nam-do is a coniferous forest area where the Pinus thunbergii is dominant as the forest trees, where the geology of this area is composed of the Precambrian Nangrim group, gneiss, and mixed gneiss, with a lot of weathering; therefore, there is a concern of additional land creeping. The soil type of the land crept area was slightly dry brown forest soil (B2), and the soil depth (cm) was 30-60 cm or less, which was the same as that with the domestic average soil depth $(30-60 \mathrm{~cm}$, Jung, 2012). From the particle size analysis, the content (\%) in sequence appeared (sand: gritsand : clay was 45.2: 41.0: 13.8) which was a loam, and among the slopes of the target area, the steep slopes ( $58 \%$ or more, $30^{\circ}$ or more) was accounted for the most at $78.8 \%$, followed by $3.0 \%$ of the steep slopes $\left(47-58 \%, 25^{\circ}-30^{\circ}\right)$, and $3.0 \%$ of steep slopes $\left(37-47 \%, 20^{\circ}-25^{\circ}\right), 1.9 \%$ of the sloped area $\left(27-37 \%, 15^{\circ}-20^{\circ}\right)$, and $3.8 \%$ of the flat area $\left(<9 \%,<5^{\circ}\right)$ including gently sloped area $\left(9-27 \%, 5^{\circ}-15^{\circ}\right)$.

The upper part of the talus area has a gentle slope, and the lower part has a steep slope. The elevation distribution has been shown at $200-300-\mathrm{m}$ with $86.1 \%$ the most, at $100-200 \mathrm{~m}$ with $5.2 \%$, and at $300-$ $400 \mathrm{~m}$ with $8.7 \%$. The geology of the target area was classified based on the geological map. During an on-the-spot investigation, the size of the investigated area (length $\times$ width $\times$ depth of collapse) and the location of tensile cracking were identified using GPS. The gap and cut slope were measured. Location characteristics, such as the parent rock, bearings, shape, and mountain slope of the land crept area, etc., were investigated and analyzed using GIS (Arc map Ver. 10.8) (Arc map Ver. 10.8). The damaged condition of the slopes caused by the land creeping was identified, and the joint of slope, direction, and spacing of the joints were investigated. The strike and dip of the joint were investigated on-site using a clinometer.

Investigations have been conducted as follows: a strike direction by the direction of the horizontal line existing on the joint surface; the direction of a dip by the inclination of the steepest line existing on the joint surface sloped from the horizontal; and the inclination direction measured clockwise from true north. 
To identify the topographical characteristics and signs of land creeping occurrence, the characteristics and microtopography of location where land creeping occurred were investigated using a topographic map $(1: 25,000,1: 50,000)$. (Varnes, 1978; Jau et al., 2000). The crept land areas were classified based on the parameters affecting land creeping, including the parent rock, dip, strike, soil type, soil physics, and the type of land creeping occurrence shown in Park et al. (2005), Park (2015), and Takaya (2017), and the slopes of the crept land area were investigated by dividing them into straight, arc, and horseshoe.

$500 \mathrm{~g}$ of soil was collected and analyzed by the Korea Forestry Promotion Institute (KOFPI) for soil physics. For the surface geological investigation, electric resistivity survey, soil and geological properties test, and drilling survey were conducted on three points, and to identify the traces of land creeping occurrences in the past, aerial photos for the target area (scale; 1:5,000) in years of 1993, 2000, 2010, and 2019 were acquired using the land information platform. The soil hardness at each level was measured thrice using a penetration-type soil hardness tester (Daiki, DIK-5520) that can measure up to a soil depth of $90 \mathrm{~cm}$ to identify the soil bulk density differential between the upper and lower regions where the tensile cracking occurred. The permeability rate for $100 \mathrm{cc}$ of soil collected using a soil sampler was determined using a water permeability measuring device and by conducting the constant head permeability test (Fig. 8). (Daiki, DIK-4000). The calculated number was then used to calculate the soil's permeability coefficient.

\section{Result And Review}

1. Overview of the target area and results of aerial photo analysis

The tensile cracking, gaps, and collapsing had occurred in the target area due to land creeping after the construction of the forest road, and as a result of three times repeating the vegetation survey on a quadrat with the size of $20 \mathrm{~m} \times 20 \mathrm{~m}$ in the crept land area, the Pinus thunbergii has been found to be the most spread vegetation in the crept land area, pine trees, and oyster oak trees in the upper layer, and juniper and camellia trees are growing in the middle layer. There are spreads of shrubs, such as serrata, spruce, and red spruce, and bibichu and festuca are spread in lower vegetation layers. Pine trees and Rigida pines are the dominant species, indicating that these have been considerably reforested by erosion projects in the past (Choi, 2018). It is assumed that the wasteland being greened and granitic gneiss beneath the fallen leaves and branches being weathered through the soiling process played a role in accelerating the subterranean land creeping (Choi, 2018; Park et al., 2018).

The first land creeping occurred in 2000. Distinguishing a landslide occurred area (Debris flow) and soil runoff area (Soil runoff) is possible by visually reading out a high-resolution satellite image in a target area of natural changes (Lee and Kim; 2011); no traces of land creeping were found in 1993, as a result of analyzing the high-resolution aerial photos of the 51-m-class (portal map service site; Daum) and the land information platform in 1987 (Fig. 2), and the area damaged by the primary land creeping was $1,990.2 \mathrm{~m}^{2}$ as a result of analyzing the aerial photos in 2000. As a result of the on-site investigation of this area, the traces of collapse caused by tensile cracking were clear, and the surface area was similar to 
the result calculated using the aerial photograph. There were gaps and tensile cracks at the upper end of the area where tensile cracking and gaps with a width of $3.5 \mathrm{~m} \times$ length of $7.5 \mathrm{~m}$ and a depth of $1.2 \mathrm{~m}$ had occurred by collapsing in March 2020. After that, the second land creeping occurred on March 31, 2020. As a result of the investigation, the damaged surface area by the land creeping was found to be $43,176.0 \mathrm{~m}^{2}$, and the volume caused by the land creeping was $107,940.0 \mathrm{~m}^{3}$, and the damaged surface area of the second land creeping was approximately 21.7 times that of the first one.

When analyzing the areas cut while opening the forest road in the target area to be investigated, it was found that the joints being developed were nearly vertical and the weathering had occurred deeply along the joint surface so that the weathered formation developed about $30 \mathrm{~cm}$ between the horizontal joints. Landslides are widespread when worn soils are soaked with water because they shape soils with high clay content. The joint surfaces of land creeping landslides in this area classify them as wedge-shaped landslides. The landslide in this location occurred due to the deep geological and topographical causes of weathering formation and the cutting of the slope due to the construction of the forest road.

\section{Topographical analysis of target area using GIS}

The target area was a typical land creeping-type landslide area formed by groundwater, and the type was a relative ground topography of convex ( $\square$ ), which belonged to a weathered rock land creeping-type landslide and the land creeping had occurred in the convex area ( $\square)$. In the target area to be investigated, the ratio $\mathrm{L} / \mathrm{W}$ of the width $(\mathrm{W})$ to the length $(\mathrm{L})$ of the land crept area was 1.5 or less and approximately 0.8 , and the thickness of the soil block was lower than that of both sides along the centerline of the horseshoe-shaped from the head at the beginning of the occurrence. It corresponds to the horseshoe type, which occurs in thick cases (Park et al., 2018). Furthermore, the convex-shaped area (অ) on the slopes affects land creeping and is continuously pushed in the form of a base, and the all-stone retaining wall functions as a raised end section at the lower part (National Institute of Forest Science, 2017). Land creeping had occurred at the inquiry target region in the relatively high convex topography ( $($ ). It is considered a result of elements affecting land creeping, such as talus at the upper part of the slope (Park et al., 2019).

As a result of conducting the on-site GPS survey of the area where the collapse had occurred (inner boundary line) in the investigation target area, and the area at risk of additional land creeping (outer boundary line) in the event of a local downpour in the future (Fig. 8), the area of the outer boundary was analyzed to be approximately $3.6 \mathrm{ha}$, and the landslide hazard grade, direction, slope, elevation, and geology were analyzed using the digital topographic map of the area (Figs. 9-12) with GIS (Arc map Ver. 10.8).

The Korea Forest Service assigns weights to topographic factors (slope, orientation, length, curvature, topographic wetness index), stock map, diameter class, soil depth, and parent rock and divides them into landslide hazard Grades 1-5. As a result of analyzing the landslide hazard grade in the area based on the seven criteria specified by the Korea Forest Service, it was found to be $0.5 \%$ for grade $1,26.6 \%$ for grade 2 , 
$48.4 \%$ for grade $3,20.1 \%$ for grade 4 , and $20.1 \%$ for grade $5.4 .3 \%$. Thus, according to the National Institute of Forest Science (2017), it was found that the creeping land area is different from common landslides as most of the landslide hazard grades are 3-5 grades and nongrade areas are included.

As a result of analyzing the direction distribution of the target area, $63.0 \%$ has been identified to be in the east direction, $23.9 \%$ in the southeast direction, $5.2 \%$ in the south direction, $4.3 \%$ in the northeast direction, $2.4 \%$ in the southwest direction, and $1.1 \%$ in the west direction. In other words, when compared with the results of analyzing the direction of growing in distortion of trees in the past due to the land creeping, the land creeping direction is found to be growing toward the east and southeast. Most of the results are consistent with the direction of the outflow of groundwater that has the most significant effect on the land creeping. These findings are consistent with the conclusion that microtopography during long-term terrain changes considerably affects land creeping (Takaya. 2017, Park et al., 2019). Furthermore, a phenomenon has been discovered in which trees are grown bent in the direction of the contour line in areas where tensile cracking and gaps occurred in the target area (Park et al., 2021), and as a result of analyzing the elevation distribution, result has been consistent with the study result (National Institute of Forest Science, 2017) that 200-300 m were the most at $86.1 \%$.

\section{Geology of the target area}

In the investigation area, there was an approximate gap of $1.2 \mathrm{~m}$ caused by the first land creeping that occurred 20-30 years ago (elevation $\left.266 \mathrm{~m}, \mathrm{~N} 35^{\circ} 1^{\prime} 59^{\prime \prime}, \mathrm{E} 127^{\circ} 30^{\prime} 49.80^{\prime \prime}\right)$ due to the recent cutoff of the slopes following the forest road opening; the second land creeping has been progressed, and an additional gap (approximate length of $80 \mathrm{~m}$ and height of $1.5 \mathrm{~m}$ ) has occurred. There was aberrant tree growth surrounding the first region of occurrence, and groundwater was drained from the cutoff section of the forest road, the weathering of the strata was exceptionally well developed, and the weathered layer of the collapsed area was clayed and vulnerable to land creeping. Concern exists regarding the occurrence of additional land creeping as the bedrock is floating due to the distribution of convex-shaped talus ( $\square$ ) in the lower part of the concave area (₫). Park (2018) and the National Institute of Forest Science (2017) have reported that slope cutting in talus areas are vulnerable to land creeping, and as shown in Mari (Park et al., 2005), Sangdong-myeon, Gimhae-si, Korea, the cutoff of the mountain angle resulting from the opening of the forest road seemed to be the cause of the reoccurrence of the land creeping.

As a result of analyzing the geological map $(1: 50,000)$ and the strata and main constituent rocks of the target area, it was identified to be in the Precambrian period with low integrity and weathering (Takaya, 2017), and the supergroup was the Nangrim stratum, which was vulnerable to the land creeping. The main constituent rocks were metamorphic rocks in which weathering was relatively severe, and thus, land creeping quickly occurred (Park, 2018). The landslide scrap of the target area was clear, there were no other strata or intrusive rocks, and the rocks were investigated in a state in which weathering had progressed significantly (Tomio et al., 1990; Kim et al., 2015; Choi, 2018). The faults and folds appeared, and the strike was in the direction of $\mathrm{N} 13^{\circ} \mathrm{SE}$. The discontinuity surface promoted land creeping in the same direction as the slope (Park et al., 2019). The number of joints was discovered to be three or more, 
and the joint interval was thick $(6-20 \mathrm{~mm}$ ) and responsive to external variables (National Institute of Forest Science, 2017; Park, 2018). According to the direction and spacing of the joints, as the number of directions of joints increases, it is discovered that land creeping occurs more quickly, which is consistent with the findings of previous studies (Kim et al., 2015; Takaya, 2017; Park et al., 2019), which show that with denser discontinuities and more number of directions, the more vulnerable it is to land creeping, and the easier it is to detect (Kim et al., 2015; Takaya, 2017; Park et al., 2019). Meanwhile, the strike direction of the rock joint in the forest road adjacent to the land crept area was $E 70^{\circ} \sim 77^{\circ}$. The rock formation on the opposite strike was $\mathrm{N} 67^{\circ} \sim 80^{\circ} \mathrm{E}$, which appeared opposite to the land crept area. The lower rock of the groundwater effluent point in the area where the collapsing progressed because the land creeping was progressing in the $S 17^{\circ} \mathrm{W}$ direction. The joint of the collapsed rock at the top was $\mathrm{N} 65^{\circ} \mathrm{W}$, indicating that the collapse proceeded in the valley direction.

\section{Soil environmental parameter analysis}

\subsection{Soil dispersion}

Checking the possibility of soil loss between the soil at a depth of 20, 100,200, and $250 \mathrm{~cm}$ from the surface soil and the collapsed weathered rocks is necessary to observe if the clay and groundwater between the bedrock and groundwater are leaching out by groundwater or rainfall infiltration The Crumb Test (ASTM D 6572-06) was conducted to check the soil dispersion by collecting $100 \mathrm{~g}$ of soil, such as clay soil and groundwater runoff. The soil's dispersion indicates the extent to which the aggregates of the soil are decomposed by water, so that the possibility of soil erosion and loss caused by the flow of groundwater can be confirmed. Soils with a high degree of dispersion are very vulnerable to groundwater's surface and internal erosion (McCook, 1991; Marcus H, 2009).

The soil dispersion degree was measured at depths of 20,100,200, and $250 \mathrm{~cm}$ from the surface soil and after 1 hour, it was found to be mild at a soil depth of $20 \mathrm{~cm}$ but severe at soil depths of 100,200, and $250 \mathrm{~cm}$. In addition, the clay soil between the bedrock was mild to severe. It was also discovered to be a severe problem in the area in which the groundwater was leaking. The degree of dispersion in this area was similar after $1 \mathrm{~h}$ and $2 \mathrm{~h}$, and erosion was discovered to proceed swiftly within $1 \mathrm{~h}$. In particular, it was analyzed that erosion occurred fast when groundwater flowed out, increasing the risk of land creeping in the direction of groundwater outflow.

\subsection{Moisture measurement by each soil depth}

Soil moisture content (gravitational moisture content, porous volume), maximum water capacity, weight water content, and permeability coefficient have been measured up to a soil thickness of $250 \mathrm{~cm}$ in the area collapsed due to land creeping. After collecting the soil thrice in $100 \mathrm{cc}$ cans, soil collection was analyzed using a soil sampler for collapsed areas in the target area. Among the soil moisture content, topsoil exhibited the highest gravitational moisture content at $32.0 \%$. As for the porous volume content, the topsoil was $34.9 \%$ as the topsoil was deeper, and the pore volume decreased as the topsoil became deeper. At a depth of $250 \mathrm{~cm}$, it was $34.1 \%$, which was lower than that of the topsoil but exhibited a 
similar trend. This was considered to be the result of the condition of the collapsed soil being composed very inhomogeneously. The maximum water capacity was $48.9-54.1 \%$ from the topsoil to the soil depth of $250 \mathrm{~cm}$, and the weight water content was in the range of $0.40-0.50 \%$. The permeability coefficient of the soil was the highest $(0.0173 \mathrm{~cm} / \mathrm{s})$ at a depth of $200 \mathrm{~cm}$, and at a depth of 20 and $100 \mathrm{~cm}$, low values of 0.0052 and $0.0035 \mathrm{~cm} / \mathrm{s}$ were identified, respectively. And appeared at $0.0148 \mathrm{~cm} / \mathrm{s}$ in the topsoil, but again showed a low value at $250 \mathrm{~cm}$ to $0.0080 \mathrm{~cm} / \mathrm{s}$. Similarly, the trend of permeability was dependent on the depth of the soil; therefore, the rainwater deposited on the soil during accumulating of rainfall in a place with a low permeability coefficient, and it was identified that the land creeping occurred while the groundwater was being pushed out at once to a place with a high permeability coefficient (Park, 2018), and as shown in the study results of Woo (1992) and Choi (2018), the soil structure is vulnerable to the land creeping.

Table 1

Analysis by each depth of the soil of the investigation target area

\begin{tabular}{|c|c|c|c|c|c|c|}
\hline \multirow{2}{*}{$\begin{array}{l}\text { Soil } \\
\text { depth } \\
\text { (cm) }\end{array}$} & \multicolumn{2}{|c|}{ Soil moisture content } & \multirow{2}{*}{$\begin{array}{l}\text { Maximum } \\
\text { water holding } \\
\text { capacity (\%) }\end{array}$} & \multirow{2}{*}{$\begin{array}{l}\text { Weight } \\
\text { moisture } \\
\text { content } \\
(\%)\end{array}$} & \multirow{2}{*}{$\begin{array}{l}\text { Volume } \\
\text { moisture } \\
\text { content (\%) }\end{array}$} & \multirow{2}{*}{$\begin{array}{l}\text { Coefficient of } \\
\text { permeability } \\
\text { (cm/sec) }\end{array}$} \\
\hline & $\begin{array}{l}\text { Gravitational } \\
\text { water } \\
\text { content (\%) }\end{array}$ & $\begin{array}{l}\text { Porous } \\
\text { volume } \\
\text { (\%) }\end{array}$ & & & & \\
\hline $\begin{array}{l}\text { Surface } \\
\text { soil }\end{array}$ & 32.0 & 34.9 & 54.1 & 0.50 & 0.54 & 0.0148 \\
\hline $20 \mathrm{~cm}$ & 27.2 & 30.3 & 53.0 & 0.50 & 0.53 & 0.0052 \\
\hline $100 \mathrm{~cm}$ & 26.4 & 29.8 & 51.2 & 0.43 & 0.51 & 0.0035 \\
\hline $200 \mathrm{~cm}$ & 27.7 & 30.0 & 48.9 & 0.40 & 0.49 & 0.0173 \\
\hline $250 \mathrm{~cm}$ & 30.6 & 34.1 & 52.9 & 0.48 & 0.53 & 0.0080 \\
\hline
\end{tabular}

\subsection{Particle size analysis of target area}

The soil type of the land crept area was slightly dry brown forest soil (B2), and the soil depth was relatively shallow with $<30-60 \mathrm{~cm}$. This is a result of the distribution of the talus zone, and the soil depth was relatively more in the left and right parts of the area where the collapse occurred due to the land creeping. It was found that the moving zone (remnant lamination, depth, $\mathrm{cm}, \mathrm{A}+\mathrm{B}+\mathrm{C}$ layer) corresponded to $100-200 \mathrm{~cm}$. After collecting $500 \mathrm{~g}$ of soil from the area collapsed due to the land creeping and the control area where land creeping did not occur, the average soil pH was $5.95(4.90-6.60)$ as a result of particle size analysis and soil and soil pH analysis at the Korea Forestry Promotion Agency. It was higher than the average $\mathrm{pH}$ of forest soil in Korea (Jeong et al., 2002). The content (\%) of sand, silt, and clay of the topsoil in the creeping land area were 45.2: 41.0: 13.8, which was determined to be loam, and the natural mountain area was 81.7: 16.1: 2.2, which was determined to be loamy sand, based on particle 
size analysis. and collapsed soil by landcreep was 52.9: 30.3: 16.9, which was determined to be loamy sand, lastly soil at the groundwater outlet result was 64.2: 23.8: 12.0 analyzed loamy sand, so The soil content of landcreep and soil content of each soil were found to differ based on the location of the natural mountain area used as a control and the area where land creeping occurred. And the heterogeneous soils (Tomio et al., 1990; Kim et al., 2015) exhibited soil characteristics vulnerable to the land creeping.

Table 2

Soil particle size analysis in areas where land creeping occurred in natural mountains

\begin{tabular}{|c|c|c|c|c|c|}
\hline \multirow[t]{2}{*}{ Site } & \multicolumn{3}{|c|}{ Grading analysis(\%) } & \multirow[t]{2}{*}{ Soil texture } & \multirow[t]{2}{*}{ Soil ph } \\
\hline & sand & silt & clay & & \\
\hline $\begin{array}{l}\text { Land creep } \\
\text { Surface soil }\end{array}$ & 45.2 & 41.0 & 13.8 & Loam & 4.9 \\
\hline $\begin{array}{l}\text { Land creep } \\
\text { Sedentary } \\
\text { Deposit }\end{array}$ & 52.9 & 30.3 & 16.9 & Sandy Loam & 5.7 \\
\hline $\begin{array}{l}\text { Landcreep } \\
\text { Groundwater } \\
\text { Elution point }\end{array}$ & 64.2 & 23.8 & 12.0 & Sandy Loam & 6.6 \\
\hline $\begin{array}{l}\text { Normal site } \\
\text { (control site) }\end{array}$ & 81.7 & 16.1 & 2.2 & $\begin{array}{l}\text { Loamy } \\
\text { Sand }\end{array}$ & 6.6 \\
\hline
\end{tabular}

\subsection{Soil hardness of the target area}

The soil hardness for each soil depth was measured thrice using a penetration-type soil hardness meter (Daiki, DIK-3300) to measure up to a depth of $90 \mathrm{~cm}$ (Table 3). Soil hardness $\left(\mathrm{kgf} / \mathrm{cm}^{3}\right)$ was measured for the areas at risk of land creeping, the boundaries of the areas at risk of land creeping (the boundary between the collapsed areas and the areas at risk of land creeping), the areas collapsed due to land creeping, and the control group in which no land creeping occurred. For the soil depth, $80 \mathrm{~cm}$ of the area was at risk of land creeping, $20 \mathrm{~cm}$ at the boundary of the land crept area, $40 \mathrm{~cm}$ at the collapsed area, and $25 \mathrm{~cm}$ in the control area The control area in the areas at risk of land creeping and the boundary area was hardness than nature soil. Because The soil hardness which was assumed to be due to the presence of talus and weathered rocks underground. Furthermore, the landslide collapsed area's soil hardness quickly dropped below $30 \mathrm{~cm}$ of soil depth. This is considered to be the case because the soil hardness 
was quickly broken as the higher soil mass was pushed down, causing the collapse below. As shown in Table 3, the upper-end part of the tensile crack caused by land creeping exhibits a relatively less disturbed state, whereas the lower part of the tensile crack caused by land creeping exhibits lower soil hardness due to disturbance and disintegration, and it was discovered that the soil disturbance caused by land creeping affected the soil hardness.

Table 3

Soil hardness $\left(\mathrm{kgf} / \mathrm{cm}^{3}\right)$ in areas at risk of land creeping, the boundary of the land crept area, collapsed areas by land creeping, and control areas (natural mountain areas)

\begin{tabular}{|lllll|}
\hline $\begin{array}{l}\text { Soil depth (cm)/Soil hardness } \\
(\mathbf{k g f} / \mathrm{cm})\end{array}$ & $\begin{array}{l}\text { Landcreep } \\
\text { dangerous } \\
\text { area }\end{array}$ & $\begin{array}{l}\text { Landcreep } \\
\text { boundary }\end{array}$ & $\begin{array}{l}\text { Landcreep } \\
\text { area }\end{array}$ & $\begin{array}{l}\text { Normal site } \\
\text { (control site) }\end{array}$ \\
\hline 0 & 2.2 & 7.2 & 4.0 & 1.5 \\
\hline 5 & 5.5 & 12.0 & 9.0 & 3.0 \\
\hline 10 & 10.1 & 2.0 & 11.0 & 4.0 \\
\hline 15 & 15.0 & 16.1 & 8.5 & 5.5 \\
\hline 20 & 15.2 & 17.5 & 10.0 & 8.5 \\
\hline 25 & 15.2 & - & 10.5 & 13.5 \\
\hline 30 & 15.2 & - & 10.0 & - \\
\hline 40 & 15.5 & - & 2.0 & - \\
\hline 50 & 19.0 & - & - & - \\
\hline 60 & 21.0 & - & - & - \\
\hline 70 & 21.0 & - & - & - \\
\hline 80 & 22.0 & - & - & - \\
\hline 90 & - & - & - & - \\
\hline
\end{tabular}

5. Analysis of the flow duration of groundwater

The land creeping is closely related with groundwater (Woo, 1992; Park, 2015); the investigation target area has a stream flowing downstream; when it rains, groundwater flows out from the forest slope coincidentally with the direction of the land creeping and enters into the stream. The groundwater is assumed to be easily flowing in the lower part of the land crept area and the lower part of the tensile cracked, affecting land creeping (Park, 2018; Choi, 2018). In other words, the electrical resistivity value 
distribution of the lateral line L-1 is $632-8,735 \Omega \mathrm{m}$, indicating a very high distribution. This was assumed to be affected by gravel, gravel-cobble, and megalith mixed in the soil layer. There is a clear difference in electrical resistivity at the $65 \mathrm{~m}$ point in which the slope activity is confirmed due to land creeping; this is the effect of the increase in porosity resulting from the relaxation of the soil by the slope activity, or the effect of the groundwater in the soil, and the strange seepage zone is assumed to be distributed up to 10 $\mathrm{m}$ below the surface, and it is affected by the relaxation of the soil layer and the groundwater up to $10 \mathrm{~m}$ below the surface. As a result of the electrical resistivity survey of the L-2 sideline, the distribution of electrical resistivity values is 609-20,667 $\Omega \mathrm{m}$, indicating a very high distribution, which is affected by gravel, gravel-cobble, and megalith mixed in the soil layer. In particular, the electrical resistivity crosssectional diagram shows a low electrical resistivity distribution at starting and ending points. The leakage water observed at the downstream tip is assumed to be flowing and leaking to the downstream slope along the topographical gradient centered on the low anomalous seepage zone caused by the effect of groundwater. The land creeping proceeds in the directions of $\mathrm{S} 15^{\circ} \mathrm{E}, \mathrm{S} 20^{\circ} \mathrm{E}, \mathrm{S} 25^{\circ} \mathrm{E}$, and $\mathrm{S} 30^{\circ} \mathrm{E}$, and this result was consistent with the direction along the flow duration of groundwater by the electrical resistivity survey, which was consistent with the results of Lee, et al. (2019), and Park et al. (2019).

\section{Summary Of The Result And Conclusion}

1. In the target area, the first land creeping occurred about 20 years ago, in 2000 , and due to the recent forest road opening, the second land creeping has occurred. As a result of the analysis of the aerial photos, the damaged surface area of the first land creeping was found to be 1,990.2 $\mathrm{m}^{2}$. The damaged surface area by the second land creeping was found to be 43,176.0 $\mathrm{m}^{2}$. The land creeping in the target area is considered to be directly caused by specific geological or topographic parameters with deep weathering zones and artificial excavation due to the opening of forest roads.

2 Using the digital topographic map of the target area, the landslide hazard grade, direction, slope, elevation, and geology have been analyzed by GIS. Most of the landslide hazard grades at the target area were relatively low-risk grades, such as Grades 3-5. As the growth direction of trees and the outflow direction of groundwater coincided, predicting the direction of the land creeping would be probably be possible, thus preparing the basis for preventive evacuation measures.

3. As a result of the geological and topographical analysis of the target area, characteristics such as the primary constituent rocks of the target area are found to be metamorphic rocks that have undergone considerable weathering, and the discontinuity surface was in dense, the number of directions was not constant, the changes of erosion and permeability were severe, and the soil content and soil were not constant, etc.; therefore, it was found to have a structure that is vulnerable to land creeping.

As analyzed in this paper, and as the general characteristics of land creeping being presented in previous studies have reliability, it is necessary, through additional study, to identify the directions of progression of the land creeping and prevent damages caused by forest disasters, such as precautionary evacuation. 


\section{Declarations}

Funding \& Acknowledgment

This study was conducted with the support of "R\&D Program for Forest Science Technology (Project No. 2021347B10-2123-CD01)" provided by Korea Forest Service (Korea Forestry Promotion Institute).

Compliance with Ethical Standards

To the best of our knowledge, no conflict of interest, financial or other, exists. We have included acknowledgements, conflicts of interest, and funding sources after the discussion

The authors have no relevant finanical or non-financial interests to disclose

\section{References}

1. Anderson MG, Richards KS (1987) Slope stability. Wildly and Sons pp 210

2. Auzet AV, Ambroise B (1996) Soil creep dynamics, soil moisture and temperature conditions on a forested slope in the granitic Vosges Mountains, France. Earth Surface Processes and Landforms 21(6):531-542

3. Choi K (2018) Geological characteristics of land creep in Korea. Korean Society of Forest Environment Research 21:108-117

4. Jau JG, Park SJ, Son DS, Joo SH (2000) The effects of geological and topographical features on landslide and land-creep. Journal of Korean Forest Society 89(3):323-334

5. Jeong JH, Koo KS, Lee CH, Kim CS (2002) Physico-chemical properties of Korean forest soils by resions. Journal of Korean Forest Society 91(6):694-700

6. Kim CS, Park JH, Cho HS, Ma HS, Lee GS (2015) Physiochemical properties of organic and soil horizon in restoration area following forest landslide by creeping soils. Journal of Agriculture \& Life Science 49(6): 27-35.

7. Kim HG (2004) Slope stability and characteristics of shallow landslide occurred in granite hillslopes. Master. Thesis, Kyung Hee University, Seoul, Korea. pp.150

8. Krag R, Higginbotham K, Rothwell R (1986) Logging and soil disturbance in southeast British Columbia. Canadian Journal of Forest Research 16(6):1345-1354

9. Korea National Geographic information Institute (2021) Korea aerial photograph website. http://map.ngii.go.kr/mn/mainPage.do. Accessed 25 Nov 2021

10. Lee MK, Kim GW (2011) A comparison of landslide features using aerial photos. KSEG Conference April 7-9 Jeju pp.227-228

11. Lee MS, Park JH, Park YS (2019) Analysis of characteristics using geotechnical investigation on the slow-moving landslides in the Pohang-si area. Journal of Korean Forest Society. 108(2):233-240 
12. Marcus H (2009) Dlspersive sols and their management. Sustainable land use department of primary industries and water. pp.38

13. Matsukura Y, Tanaka Y (1983) Stability analysis for soil slips of two gruss slope in southern abukuma mountains, Japan. Transactions Japanese Geomorphological Union 4:229-239

14. Montgomery DR, Sullivan K. Greenberg HM (1998) Regional test of a model for shallow landslide. Hydrological Processes 12:943-955

15. National Institute of Forest Science (2017) A precedent investigation of the foreign and in the country status of landslide by land creeping, rehabilitation and management. National Institute of Forest Science Report. pp.153.

16. Park JH (2015) Analysis on the characteristics of the landslide - with a special reference on geotopographical characteristics. Journal of Korean Forest Society 104(4):588-597

17. Park JH, Choi K, Lee SG, Ma HS, Lee JH, Woo BM (2003) Analysis on the characteristics of the landslide in nasamri $(\mathbb{\otimes})$ - with a special reference on geo-topographical characteristics. Journal of Korean Forest Society 92(3):246-253

18. Park JH, Choi K, Bae JS, Ma HS, Lee JH (2005) Analysis on the characteristics of the landslide in

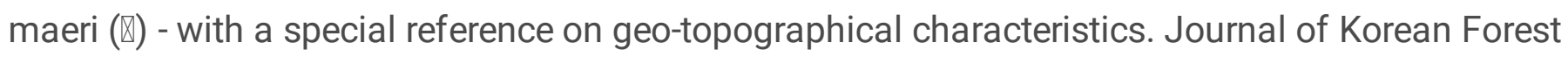
Society 94(3):129-134

19. Park JH (2018) What's land creep. Korean Society Of Forest Environment Research 21:96-107

20. Park JH (2019) Analysis of various kinds characteristics on slow-moving landslide in Pohang-si area. Journal of Agriculture \& Life Sciences. 53(4):1-11

21. Park JH, Seo JI, Lee CW (2019) The topography characteristics on the land creep in Korea. Journal of Korean Forest Society 108:50-58

22. Park JH, Ma HS, Park SG (2021) Actual conditions on the Land Creep Areas by the analysis of satellite imagery. Journal of Agriculture and Life Science 55(1):57-64

23. Sorensen S (1995) Dispersive soils: Guide for use in farm dam construction. DNRQ96017, Rural water advisory services. Department of natural resources Queensland, Brisbane

24. Takaya S (2017) Facts of landcreep. Nokdo Publication. pp.255

25. Tomio HZ, Sohei A, Takeshi N, Tosihiko ST (1990) Landslide disaster in Temanggung, Indonesia. Journal of the Japan Society of Erosion Control Engineering 42(6):57-59

26. McCook (1991) Ddisoersive clays. U.S. Department of Agriculture Soil Conservation Service Engineering Division. Soilmechanics note no.13:24

27. Varnes DJ (1978) Slope movement types and processes. Transportation Research Board Special Report. pp.11-33

28. Woo BM, (1992) Erosion contron and conservation. Hayngmunsa. pp.310

\section{Figures}




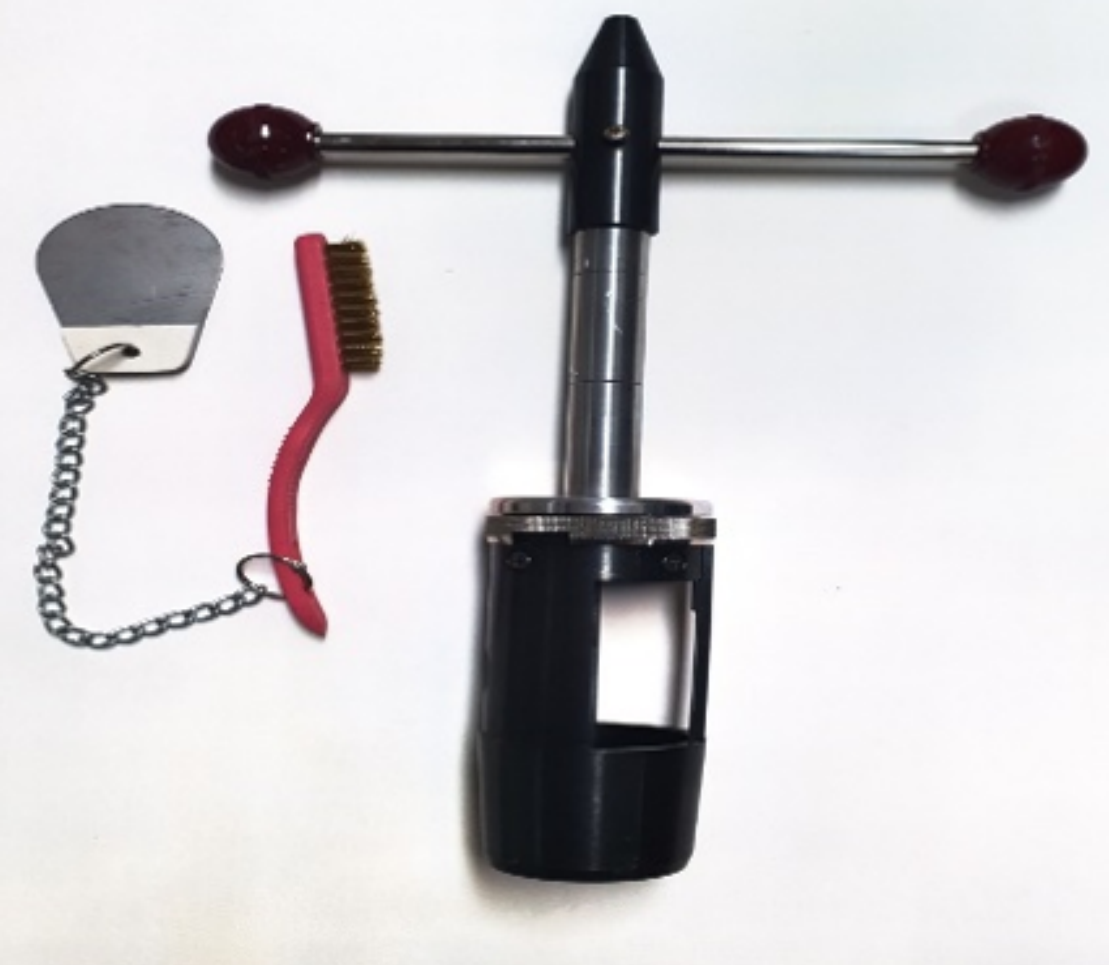

Figure 1

Soil sampler 


\section{Figure 2}

Clinometer 


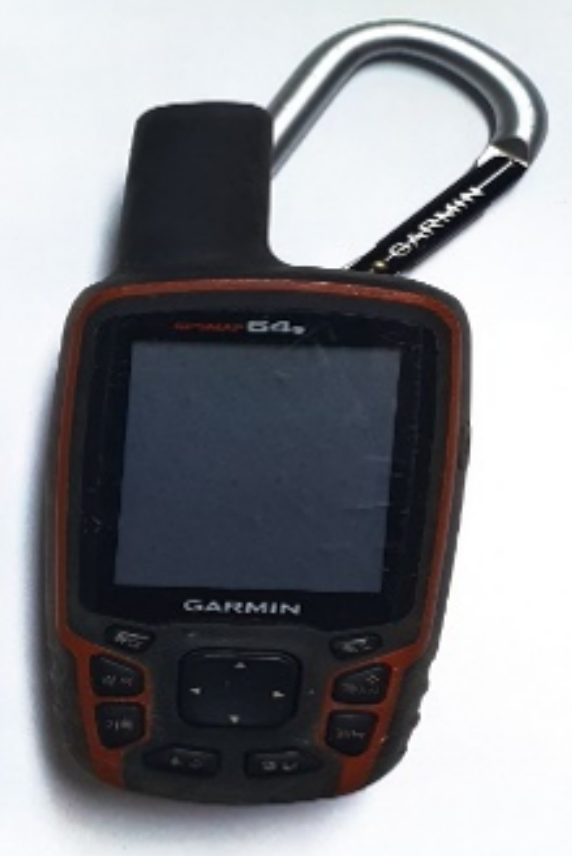

Figure 3

GPS Garmin 64s 

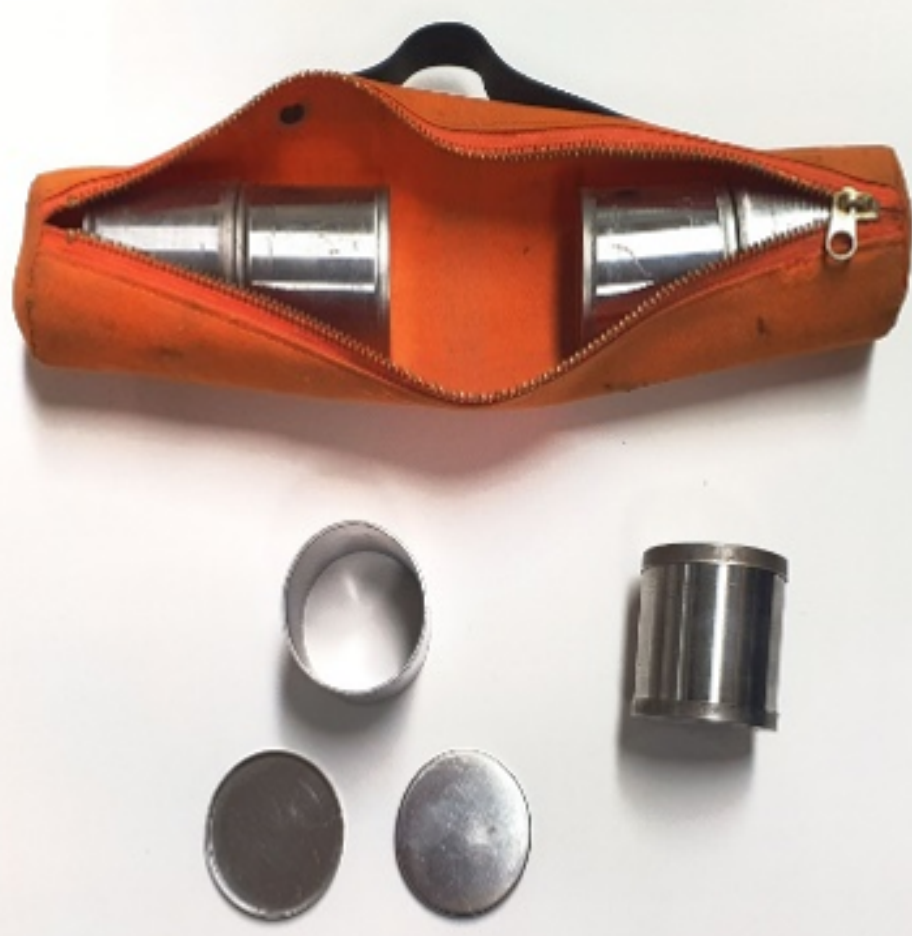

Figure 4

Soil can

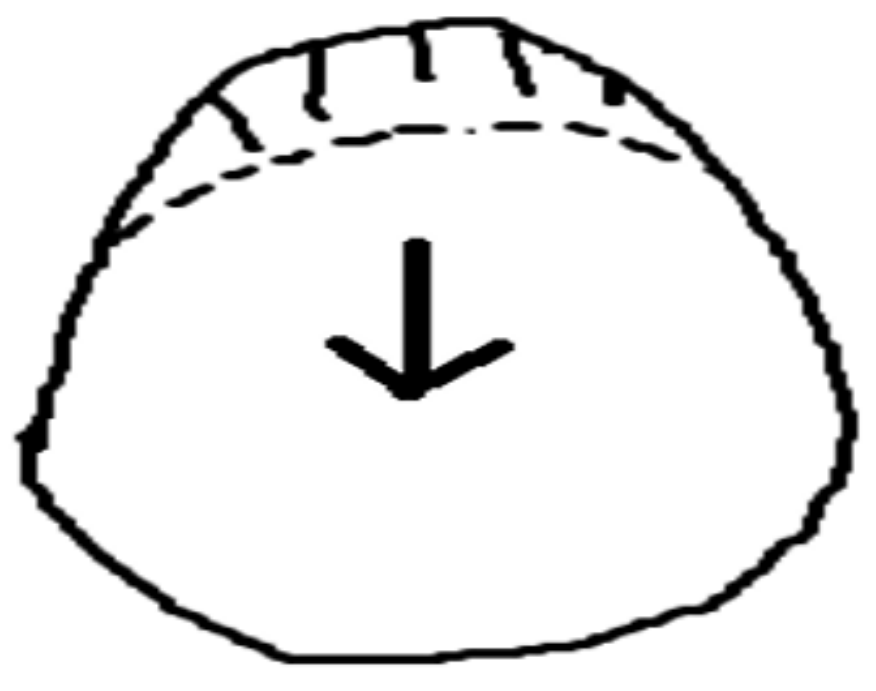

Figure 5 
Figure 6

Land crept area landslide scrap arc type

\section{Figure 7}

Land crept area landslide scrap straight type

\section{Figure 8}

Equation of constant head permeability test and test instruments

\section{Figure 9}

Map of the study site.

\section{Figure 10}

Aerial photo analysis result of the investigation target area $(1: 5,000)$

\section{Figure 11}

Collapsed and damaged areas using digital topographic maps (Mapsource, Ver.) of the investigation target area

\section{Figure 12}

Dangerous land creep area rating chart using GIS (Arc map Ver. 10.8) 


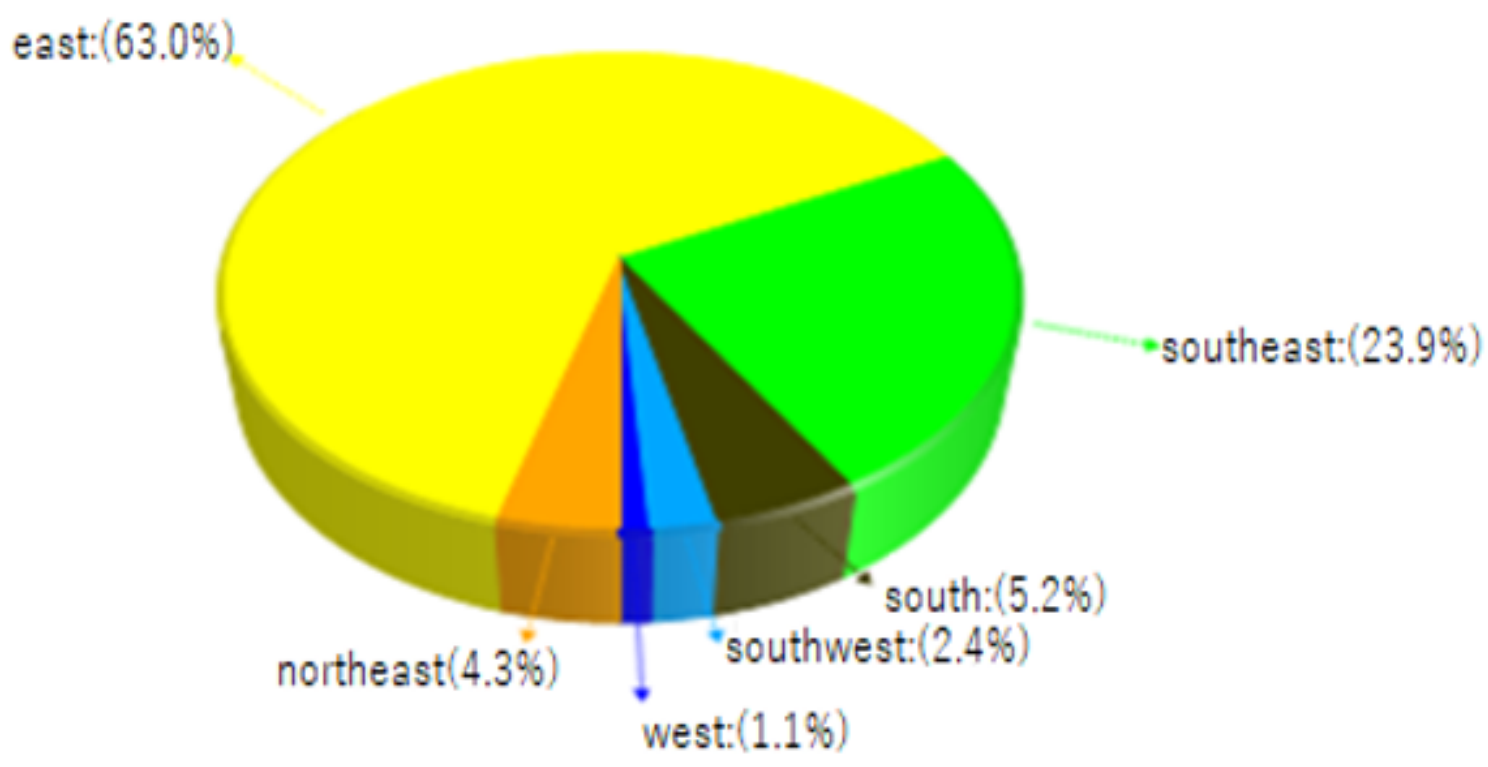

Figure 13

Dangerous land creep area Direction distribution chart using GIS (Arc map Ver. 10.8)

\section{Figure 14}

Dangerous land creep area slope map using GIS (Arc map Ver. 10.8)

\section{Figure 15}

Dangerous land creep area altitude chart using GIS (Arc map Ver. 10.8)

\section{Figure 16}

Geology of the investigation area

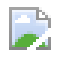

Figure 17 
Progress of weathering and the formation of a clay layer in the investigation area

\section{Figure 18}

Direction of the creeping land boundary of the target area and the joint rock direction of the collapsed area

\section{Figure 19}

Dispersion degree of soils (Sorensen S., 1995)

Figure 20

Crumb Test result of the soil in the investigation target area (after1hour)

\section{Figure 21}

Soil permeability measurement points around the collapsed area due to land creeping 
Figure 22

Direction of a slow-moving landslide

\section{Figure 23}

Result of the flow duration of groundwater by the electrical resistivity survey in the investigation target area 